\title{
Potential Opportunities and Threats to a Reintroduced Critically Endangered Mountain Bongo Population and Its Habitat at Mount Kenya Forest
}

\author{
Peter Fundi \\ Department of Environmental Studies and Resource Development, Chuka University, Chuka, Kenya \\ Email address: \\ peter.fundi@gmail.com \\ To cite this article: \\ Peter Fundi. Potential Opportunities and Threats to a Reintroduced Critically Endangered Mountain Bongo Population and Its Habitat at \\ Mount Kenya Forest. International Journal of Natural Resource Ecology and Management. Vol. 5, No. 3, 2020, pp. $102-107$. \\ doi: 10.11648/j.ijnrem.20200503.13
}

Received: July 17, 2020; Accepted: August 3, 2020; Published: August 13, 2020

\begin{abstract}
Three communities living in areas adjacent the western side of Mount Kenya forest and close to Mount Kenya Wildlife Conservancy were sampled to assess opportunities provided for by the forest, determine conservation benefits from Mountain bongo and evaluate the threats to a released bongo population and to the forest resources. Structured questionnaires were administered randomly to 120 households and interviews conducted to persons above 10 years of age. Despite a large proportion of respondents believing in community's ownership of forest resources (48\%) and it is their duty to actively protect the forest $(65 \%)$, benefits received from the forest including farming $(72 \%)$, livestock grazing and pasture extraction (14\%), access to firewood, timber and bush meat (14\%) tend to threaten the same forest. Overall, there was a significant difference $\left(\chi^{2}=24.96 \mathrm{df}=3, \mathrm{p}<0.05\right)$ on benefits received from the forest by the three communities sampled. Poverty was cited as the driving force to overreliance on forest resources for livelihood support. Kanyoni and Kangaita communities, living in squatter systems, pose more danger to the forest than the small scale farmers at Kwamwea. The high prevalence of hunting in the region (55\%) mainly for subsistence purposes $(45 \%)$ pose a major threat to a reintroduced bongo population. All livelihood support activities from the forest are however, a threat to the success of Mountain bongo reintroduction. Nonetheless, the general feeling that presence of wild bongos would boost tourism in the region $(85 \%)$ ought to be emphasized and escalate conservation education underscoring the impacts of human activities on forest resources and to Mountain bongo habitat.
\end{abstract}

Keywords: Mountain Bongo, Conservation Benefits, Reintroduction, Threats, Conservation Education

\section{Introduction}

Forest resources are a major component of the natural resource base for communities, region or country, and they play a fundamental role in the socio-economic well-being of the people in those communities [1]. This is the case for most developing countries where rural populations rely on natural resource exploitation for their livelihood. Particularly, tropical forests are of great economic significance to both urban and rural poor [2]. Besides meeting most economic needs for the rural poor by providing food, shelter, livestock pasture and alternative medicine, tropical forests are a major source of industrial wood products and a major tourist attraction [1]. According to 3, majority of rural households in developing countries, and a large proportion of urban households, depends on plant and animal products from the forests to meet part of their nutritional needs putting pressure on both animals and the habitat.

Despite having a number of successful management initiatives for biodiversity conservation at Mount Kenya forest which is a World Heritage Site, a number of threats and pressures still remain [4]. Rapid increase in human population around the forest has increased pressure on forest resources over the past three decades [5]. As resources become scarce within community land, people are turning to the neighboring protected Mount Kenya forest for livelihood support. This has led to natural resources degradation and depletion threatening wildlife inhabiting 
the forest including the endemic Mountain Bongo (Tragelaphus eurycerus isaaci).

Mountain bongo (hereafter referred to as bongo) is a critically endangered montane antelope endemic to Kenya and occurring in fragmented subpopulations in the forested zones of Mount Kenya, Aberdares, Mau and Eburu forests in Kenya [6]. Bongo numbers have declined precipitously over the last few decades rendering its populations unsustainable [7] and at the verge of extinction. The cause of their decline has touched on a number of possibilities including illegal hunting for food and trophies $[8,9]$, habitat loss $[10,11]$ and predation by lions at Aberdares National Park [9, 12]. The dramatic human population increase in Kenya's fertile mountain regions is the root cause of increased habitat destruction and a major threat to bongo's survival [13]. Grazing of livestock by local communities within the forests can also increase the risk of bongos contracting diseases, rinderpest having been attributed to bovines decline in bongo habitats in 1980s and 90s [14].

Bongo habitats have also changed over time due to shifts in vegetation communities [15]. Rapid intensification of land use in Mount Kenya-Aberdares area over the last 50 years has resulted in increased encroachment and natural resources extraction in these protected mountain forest reserves $[16,17]$. This is common in most biologically rich montane forests which cover only three percent of Kenya, and are threatened by the fast growing human population and intensive agriculture $[18,16]$. Bongos have concurrently declined throughout their range [12], with the 2018 Bongo Surveillance Program's wild population estimates being slightly more than 100 individuals in all the areas where they still occur. The population is still declining as their threats continue to escalate and none of the subpopulations in the four areas contain more than 50 mature individuals [19].

The threat to mountain bongo habitats has long been recognized, and a variety of conservation actions have been taken. Mount Kenya is a designated World Heritage Site whose upper reaches enjoy National Park status, while the lower encircling forests are under forest reserve. Forest custody now falls under the Kenya Forest Service (KFS), which has made impressive strides in minimizing the rampant illegal logging, cultivation, and settlement that took place in the forests towards the end of the $20^{\text {th }}$ century [20, 21]. Captive breeding of the subspecies has undergone profound progress. The high captive bongo population growth in the North American zoos and at Mount Kenya Wildlife Conservancy prompted their reintroduction into their natural range at Mount Kenya Forest. Success of such an initiative requires careful planning and support by the local community. In order to assess the potential success to such an initiative, this project was undertaken to evaluate the threats to a released bongo population and to the forest resources. Additionally, the study assessed the benefits local communities derive from Mount Kenya forest and community's understanding of benefits bongos would bring once released at Mount Kenya forest.

\section{Materials and Methods}

\subsection{Study Area}

This study was carried out on the western side Mount Kenya forest reserve and targeted communities adjacent Mount Kenya Wildlife Conservancy which is the main Mountain bongo breeding facility in Kenya. The conservancy bounders Mount Kenya forest and is located within Latitude $0^{0} 03^{\prime} \mathrm{N}$ and Longitude $37^{\circ} 09^{\prime} \mathrm{E}$ (Figure 1). In collaboration with the Kenya Wildlife Service, the conservancy is planning to reintroduce bongos to Mount Kenya forest and a bongo sanctuary identified $5 \mathrm{Km}$ in the forest. The forest reserve is managed by Kenya Forest Service while the conservancy is privately managed. Three communities (Kwamwea, Kangaita and Kanyoni) with varying land use practices live in the area adjacent the conservancy. Most of the people in Kwamwea practice small scale subsistence farming while others keep livestock (mainly sheep and goats) for commercial purposes. In Kanyoni and Kangaita, however, land is a limiting factor with most people venturing into illegal charcoal burning, hunting and illegal timber sale. The three communities use forest margins and forest reserve heavily for livestock grazing, temporary forest farms (shambas) and farm settlements. Most of the fairly educated youth in the area however work as guides and porters during mountain climbing safaris. Adjacent the Conservancy is William Holden Wildlife Education Center which has over the years provided extensive conservation education through outreach program and mainly targeting the three communities.

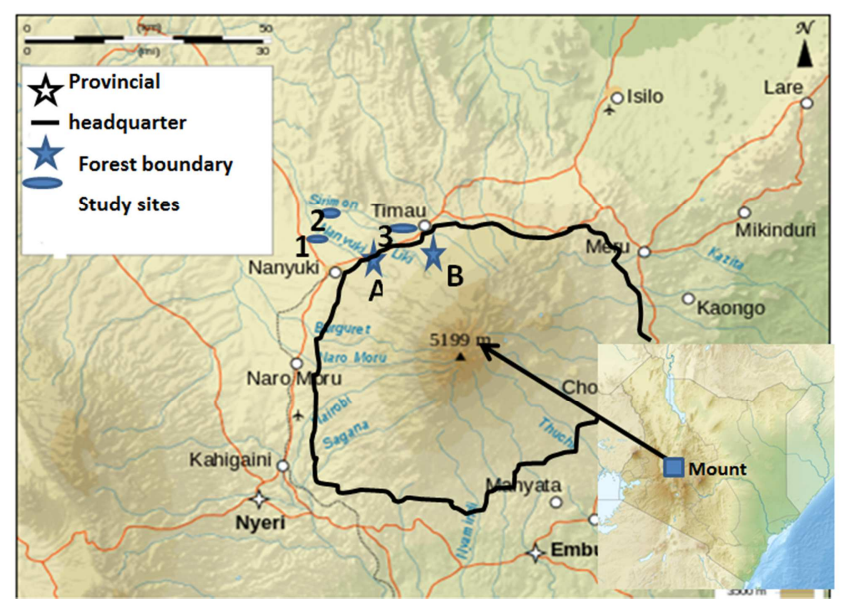

Figure 1. Map of Mount Kenya showing the locations of Mount Kenya Wildlife Conservancy (A) and the Proposed Bongo Sanctuary (B). Numbers 1, 2 and 3 indicating Kanyoni, Kwamwea and Kangaita respectively.

\subsection{Sampling}

In this study, questionnaires we used during data collection and targeted three communities on the Western side of Mount Kenya Forest. The communities represented different land use types and ownership and live in areas adjacent Mount Kenya Wildlife Conservancy and the Proposed Bongo Sanctuary. Each questionnaire was designed to gather formation on community knowledge towards forest resources 
and bongo conservation; benefits derived from forest resources; current and future benefits from bongo conservation; and threats posed on forest resources and to Mountain bongos. Both closed and open ended questions were used to capture detailed information from the community.

A stratified sample of 120 questionnaires was administered targeting both genders in the sampling frame. The targeted respondents were grouped according to age in categories of 10-20 years, $>20-45$ years, $>45-60$ years and over 60 years. Those below ten years were considered too young and therefore not sampled.

\subsection{Data Collection Method}

Questionnaires were systematically administered by interviewing one person in every third house in the sparsely populated agriculturalist community of Kwamwea and at $50 \mathrm{~m}$ intervals in the densely populated squatters dominated Kanyoni and Kangaita areas. At the households, Kish selection grid was used in selecting members to be interviewed. In cases where there was nobody in the homestead or the person is below 10 years, next homestead was considered in the survey. Questionnaires were administered in form of interviews conducted in Swahili and Kikuyu languages depending on respondent's preference. Each interview took the form of a conversation, structured around a written questionnaire consisting of general and specific questions.

\subsection{Data Analysis}

Statistical Packages for Social Scientists (SPSS) was used to analyze the collected data and graphically presented using tables. Data was analyzed for descriptive statistics using frequencies and percentages while chi-squared $(\chi 2)$ was used to test for significance differences.

\section{Results and Discussion}

Out of the 120 questionnaires projected for the survey, 107 were successfully administered, which was $89 \%$ response rate, 60 respondents being men and 47 women aged between 16 and 65 years.

\subsection{Community Awareness}

Respondents views on natural resources ownership within Mount Kenya forest had no significant difference $\left(\chi^{2}=0.41\right.$, $\mathrm{df}=2, \mathrm{p}>0.05$ ) between the three communities with $41 \%$ of those interviewed in Kanyoni believing that natural resources belong to the society and should be protected by the society $(67 \%)$. In Kwamwea, $55 \%$ of respondents believed that natural resources belong to the society and people should protect them $(67 \%)$. Only a small proportion of respondents in the three communities believed that natural resource belong to God and government should protect them (Table 1). A large proportion of women $(70 \%)$ and men $(62 \%)$ believe the society should protect natural resources in the forest. In Kanyoni and Kangaita, however, a considerable number of respondents believe that natural resources belong to the government and it is the responsibility of the government to protect them (Table 1). With most of these area's respondents being squatters, this lack of a sense of responsibility to protecting the forest endangers the same critical ecosystem their livelihood is dependent on.

A large number of respondents believe that they are the custodians (Table 1) of the forest resources with no significant difference $\left(\chi^{2}=0.94, \mathrm{df}=2, \mathrm{p}>0.05\right)$ in respondents belief regarding natural resources protection between the three communities.

Table 1. Natural resources ownership and protection views in Kanyoni, Kangaita and Kwamwea.

\begin{tabular}{|c|c|c|c|}
\hline & & Who owns natural resources in Kenya (\%) & Who should protect natural resources in Kenya (\%) \\
\hline \multirow[t]{4}{*}{ Kanyoni } & Society & 41 & 67 \\
\hline & Government & 56 & 33 \\
\hline & God & 3 & 0 \\
\hline & Not sure & 0 & 0 \\
\hline \multirow[t]{3}{*}{ Kangaita } & Society & 48 & 60 \\
\hline & Government & 40 & 40 \\
\hline & God & 12 & 0 \\
\hline \multirow[t]{4}{*}{ Kwamwea } & Society & 55 & 67 \\
\hline & Government & 33 & 33 \\
\hline & God & 9 & 0 \\
\hline & Not sure & 3 & 0 \\
\hline
\end{tabular}

Respondents awareness regarding ownership natural resources in Kenya based on their level of education had no significant difference $\left(\chi^{2}=0.73, \mathrm{df}=4, \mathrm{p}>0.05\right)$. This was expected owing to the fact that William Holden Wildlife Education Center (WHWEC) has been sensitizing locals on the importance of bongo reintroduction mainly targeting schools and organized community groups. Similarly, their view on who is responsible for protecting natural resource based on level of education had no significant difference $\left(\chi^{2}\right.$ $=4.49, \mathrm{df}=4, \mathrm{p}>0.05)$ in all the three communities.

\subsection{Community Benefits}

In all three areas sampled, a large number of respondents claimed to be benefiting from the forest with Kangaita $97 \%$, Kwamwea $97 \%$ and Kanyoni $100 \%$ of respondents benefiting from Mount Kenya forest. Farming was cited to be the main benefit (72\%) from the forest (shamba system) with Kangaita and Kwamwea having more forest farmers $(95 \%$ each) while Kanyoni had only $37 \%$ of sampled population 
farming in the forest. The shamba system had been introduced by Kenya Forest Service in an effort to enhance community support for conservation programs in the forest. In this system people own small parcels of land in the forest where they plant exotic-timber trees and ultimately abandon them to allow for rapid growth of trees. Even though locals understood the negative impacts of farming, most people pointed it as a major benefit they derive from the forest. Forest farming was a management practice which has been controversial though successful where managed well [22]. It however, remains a major threat to tropical forests [23] and has increased fragmentation of many forests resulting to extinctions of both flora and fauna [24].
Firewood, fodder and building materials extraction were other major products from the forest (Table 2). Such resource extraction has negative impacts on forest structure and diversity [25] by reducing undergrowth diversity causing an increase in tree density hence reducing browser's habitats. Controlled grazing if well implemented can, however, assist in maintenance of biodiversity [26]. This might not be true in cases of high livestock stocking rate and changing climatic conditions due to global warming leading to overgrazing of limited and water scarce ecosystems. Livestock herds might also pose competition for food and space to the wild herbivores and also transmission of diseases between them might occur.

Table 2. Percentage of the respondents benefiting from the Mount Kenya Forest and the resource they benefit with in Kanyoni, Kwamwea and Kangaita.

\begin{tabular}{llll}
\hline Benefit & Locality & & Kanyoni (\% population) \\
\hline Firewood & Kangaita (\% population) & Kwamwea (\% population) & 9 \\
Water & 16 & 5 & 0 \\
Building material. & 8 & 0 & 3 \\
Fire wood, building material, fodder & 3 & 0 & 64 \\
Firewood, fodder & 38 & 57 & 0 \\
firewood, building material & 32 & 0 & 23 \\
\hline
\end{tabular}

A good proportion of sampled population (14\%) in Kanyoni gets their protein diet (meat) from forest animals. Overall, there was a significant difference $\left(\chi^{2}=24.96 \mathrm{df}=3\right.$, $\mathrm{p}<0.05$ ) on how each community benefit from various forest resources with no significant difference in the benefits these communities obtain from the forest between men and women $\left(\chi^{2}=3.069, \mathrm{df}=5, \mathrm{p}>0.05\right)$.

A large number of those sampled $(85 \%)$ felt that reintroducing bongos at Mount Kenya forest will benefit the community in terms of tourism $(67 \%)$. This provides the reintroduction program a better chance of community support and protection of reintroduced population. Additionally, 9\% of the respondents felt that future generations will have an opportunity to see wild bongos and there is an urgent need to protect the subspecies. Some people, however, view bongo an alternative source of meat $(9 \%)$ posing a threat to the animals once reintroduced. Respondents feelings on the benefits bongos might bring once released had no significant difference $\left(\chi^{2}=0.46, \mathrm{df}=2, \mathrm{p}>0.05\right)$ between the three communities. Additionally, level of education did not influence $\left(\chi^{2}=4.39, \mathrm{df}=4, \mathrm{p}>0.05\right)$ the way people view these benefits to the society once bongos are reintroduced. With $15 \%$ of respondents not sure of the benefits wild bongos might bring, education and awareness on the importance of reintroduction as an economically viable conservation option ought to be stepped up in the area. Such initiative previously enhanced successful reintroductions of a few high-profile and charismatic vertebrates in 1970s and 1980s, including the Arabian Oryx (Oryx leucoryx) in Oman [27]. Bongo reintroduction will, therefore, be successful if only the program garners support from local communities.

\subsection{Threats to Wildlife}

Generally hunting was prevalent in the region as confirmed by $55 \%$ of respondents. While Kanyoni people practice more hunting (65\%) than Kangaita (50\%) and Kwamwea $(51 \%)$, there is no significant difference $\left(\chi^{2}=3.09\right.$, $\mathrm{df}=2, \mathrm{p}>0.05)$ in hunting prevalence between the three communities. Hunting is a major threat to wildlife within and outside forested areas in most tropical forests (Koppert et al., 1993). Most people hunted for subsistence purposes (45\%) although a number of them hunt for both subsistence and commercial $(42 \%)$ purposes. Poverty was cited to be the main reason $(85 \%)$ as to why people hunt. Despite the blame on poverty to thriving of hunting business in the region, a large proportion of respondents believed that bush meat was their main source of affordable meat protein. This is seemingly the case for most households in the developing countries as livestock meat protein is highly priced and unaffordable [28].

Hunting was actually the main cause for bongo population decline and local extinction in Kenya and is considered to be a primary reason for biodiversity loss in many tropical forests [29]. With its high prevalence within the reintroduction site, hunting poses a threat to a reintroduced population. Unless managed to sustainable levels, bush meat hunting coupled with fast growing human population remains to be a major threat to the wild bongos and general conservation of wildlife in the region.

Logging, poaching, encroachment and forest fires were other factors believed to endanger natural resources in the area. Most people felt that multiple reasons could be threatening natural resources in the forest. Thirty two percent of sampled population attributed logging to the main loss of natural resources, $26 \%$ attributed to poaching, $14 \%$ to forest encroachment, $13 \%$ to overgrazing, $11 \%$ to forest fires, $3 \%$ to drought and climate change and only $1 \%$ to shamba system. There was no significant difference $\left(\chi^{2}=2.31, \mathrm{df}=2, \mathrm{p}>0.05\right)$ 
in the way the three communities viewed these dangers as a threat to natural resources. Due to increasing human population in developing countries, demand for housing and wood fuel has increased with people resulting to logging both legally and illegally. Logging, a major threat to forest resources within Mount Kenya, mainly results in conversion of previously continuous forests to landscape mosaics of forest fragments, secondary vegetation, and ultimately agricultural areas [30].

Even as most people linked logging to fuel wood and charcoal access (83\%), they still believe it threatens biodiversity. Eighty two percent of these get firewood and charcoal from the forest and only $18 \%$ of them getting from their own farms. There was no significant difference $\left(\chi^{2}=1.8\right.$, $\mathrm{df}=3, \mathrm{p}>0.05)$ in the source of firewood and charcoal between the three communities. Such human exploitation of forest resources involves rapid and non-sustainable harvesting of particular species [31]. This results in progressive degradation of forest structure and biodiversity leaving behind standing but biologically and economically depleted forests. Conservation of forests is thus one of the greatest challenges to Kenya Forest Service involving a delicate balance between complex-fragile ecosystem, and impoverished human populations having small or no farms to meet their daily needs.

Despite farming being a major benefit the community derives from the forest, it remains a major threat to tropical forests [23] and has exacerbated natural fragmentation of landscapes affecting whole ecosystems and biotas [24]. This has been worsened by the fact that within the forest reserve and areas where proposed bongo sanctuary is located, shamba system is only meant to expand Cuppressus lucitanica plantations. This has reduced herbivores' food base due to the unpalatable and allelopathic nature of the species ultimately reducing wildlife habitats in Mount Kenya forest ecosystem.

\section{Conclusion}

Anthropogenic activities are a major threat to biodiversity and institutions charged with forests management ought to seek lasting solutions to this problem. These activities lend to the initial decline of wild bongo population and their existence in Mount Kenya forest will ultimately affect reintroduction success. Unfortunately, most activities which locals view as livelihood supporting benefits from the forest including farming, timber extraction, grazing and access to firewood are actually detrimental to the habitat and are bound to affect reintroduced population. Hunting being a major cause for wild bongo decline and the general wildlife loss in Africa, and in some instances leading to species local extinction, is still a major threat to wildlife in the region. However, studies on bushmeat off take levels in the region need to be conducted in order to ascertain how much is hunted, species targeted and consumed at the households and sold in the market.

Most people in the study area believe that bongo's release will attract more tourists in the region and therefore, creating job opportunities. If well promoted, this will come a long way in curbing poverty levels, which is a major driving force to anthropogenic forest destruction in the region. Kenya Wildlife Service should therefore, ensure that bongo release is thoroughly marketed as a key tourist attraction at Mount Kenya forest. This will be in support of Bali's World National Park Congress of 1982, which concluded that "protected areas in developing countries will survive only insofar as they address human concerns" [32].

\section{Conflict of Interest}

The author declares that there are no competing interests regarding publication of this work.

\section{Acknowledgements}

The author would like to acknowledge Mr. James Muraya who was the research assistant and the people of Kwamwea, Kanyoni and Kangaita for freely participating in this study. Additionally, I thank Fort Worth Zoo and the Bongo Foundation for providing financial support.

\section{References}

[1] Inoni, O. E. (2009): Effects of forest resources exploitation on the economic well-being of rural households in Delta State, Nigeria. Agricultura Tropica et Subtropica, 42 (1), 20-27.

[2] Roper, J. and Roberts, R. W. (1999): Deforestation: Tropical Forests in Decline. Forestry Issues No. 1999-2001, CIDA Forestry Advisers Network (CFAN). Canadian International Development Agency, Canada.

[3] Bryon, N. and Arnold, J. E. M (1997): What Futures for the People of the Tropical Forests? CIFOR Working Paper No. 19. Centre for International Forestry Research (CIFOR), Indonesia.

[4] Kenya Forest Service (2010): Mount Kenya Forest Ecosystem Management Plan, 2010-20120.

[5] Nyongesa, K. W. and Vacik, H. (2018): Fire Management in Mount Kenya: A Case Study of Gathiuru Forest Station. Forest, 9, 481.

[6] Elkan, P. W. and Smith, J. L. D. (2013): Tragelaphus eurycerus Bongo. In: Kingdon, J, Hoffmann, M (eds.) Mammals of Africa Volume IV. London: Bloomsbury, 179185 .

[7] Estes, L. D., Mwangi, A. G., Reillo, P. R. and Shugart, H. H. (2011): Predictive distribution modeling with enhanced remote sensing and multiple validation techniques to support mountain bongo antelope recovery. Animal Conservation, 14, 521-532.

[8] Estes, R. D. (1991): Bongo. In: Estes, R. D. The behavior guide to African mammals: including hoofed mammals, carnivores, and primates. Berkeley: University of California Press.

[9] Prettejohn, M. (2004): Encounters with the bongo. Swara, 27 (1): 28-30. 
[10] Kingdon, J. (1982): Bongo, Boocercus eurycerus. In: East African Mammals. Vol. III C (Bovids); An Atlas of Evolution in Africa. University of Chicago Press, Chicago.

[11] Glover, P. E., Stewart, J. and Gywnne, M. D. (1966): Masaai and Kipsigis notes on East African plants. Part 1--grazing, browse, animal associated and poisonous plants. East African Agricultural and Forestry Journal, 32: 200-207.

[12] Cheffings, A. (1997): Not guilty? Swara, 20: 29-30.

[13] Estes, L. D. (2006): Reintroducing a large herbivore: a remote sensing and modeling approach to determine the Mountain Bongo's (Tragelaphus eurycerus isaaci) past and present critical habitat. <www.rarespecies.org/LDEfldrpt.pdf. Retrieved on $2^{\text {nd }}$ May 2020>

[14] Kock, R. A., Wambua, J. M, Mwanzia, J., Wamwayi, H., Ndungu, E. K., Barrett, T., Kock, N. D. and Rossiter, P. B. (1999): Rinderpest epidemic in wild ruminants in Kenya 1993-1997. Veterinary Record, 145: 275-283.

[15] Shugart, H. H., French, N. H. F., Kasischke, E. S., Slawski, J. J., Dull, C. W., Shuchman, R. A. and Mwangi, J. (2001): Detection of vegetation change using reconnaissance imagery. Global Change Biology, 7: 247-252.

[16] Imbernon, J. (1999): Pattern and development of land-use changes in the Kenyan highlands since the 1950s. Agriculture Ecosystems \& Environment, 76: 67-73.

[17] Lambrechts, C. (2003): Aerial survey of the destruction of the Aberdare Range forests. UNEP, KWS, Rhino Ark, KFWG.

[18] Kohler, T. (1986): "Mount Kenya: The forest belt and its utilization: In Winiger, M. (Eds.): Mount Kenya area: contributions to ecology and socio-economy. African Studies Series, Geographica Bernensia, University of Berne.

[19] IUCN SSC (International Union for Conservation of Nature and Natural Resources Species Survival Commision). (2008): Tragelaphus eurycerus ssp. isaaci. In: IUCN 2020. http://www.redlist.org/. Retrieved on $3^{\text {rd }}$ June 2020.

[20] Gathaara, G. N. (1999): Aerial survey of the destruction of Mount Kenya, Imenti, and Ngare Ndare Forest Reserves. Kenya Wildlife Service, Nairobi, Kenya.

[21] Vanleeuwe, H., Woodley, B., Lambrechts, C. and Gachanja, M. (2003): Change in the state of conservation of Mount Kenya Forest: 1999-2002. Kenya Forest Working Group, Nairobi.
[22] Mathu, W. (2011): Forest plantations and woodlots in Kenya. Africa Forest Forum, Nairobi, Kenya.

[23] Myers, N. (1987): Trends in the destruction of rain forest. In: Marsh, C. and Mittermeir, R. A. (Eds) Primate conservation in the tropical rain forests. Monographs in Primatology, 9: 3-22.

[24] Bender, D. J., Contreras, T. A. and Fahrig, L. (1998): Habitat loss and population decline: a meta-analysis of the patch size effect. Ecology, 79: 517-533.

[25] Madhusudan, M. D. (2005): The global village: linkages between international coffee markets and grazing by livestock in a south Indian wildlife reserve. Conservation Biology, 19: 411-420.

[26] Brockington, D. (2002): Fortress conservation: the preservation of the Mkomazi Game Reserve, Tanzania. Indiana University Press, Bloomington, Indiana.

[27] Stanley Price, M. R. (1989): Animal re-introductions: the Arabian oryx in Oman. Cambridge University Press, Cambridge, United Kingdom.

[28] Koppert, G. J. A., Dounias, E., Froment, A. and Pasquet, P. (1993): Food consumption in three forest populations in the southern coastal area of Cameroon: In: Hladik, C. M., Hladik, A., Linares, O. F., Pagezy, H., Semple, A., Hadley, M. (Eds.), Tropical Forests, People and Food: Biocultural Interactions and Applications to Development. Parthenon Publishing Group, Paris.

[29] Fa, J. E., Currie, D. and Meeuwig, J. (2003): Bushmeat and food security in the Congo Basin: linkages between wildlife and people's future. Environmental Conservation, 30: 71-78.

[30] Harris, L. D., and Silva-Lopez, G. (1992): Forest fragmentation and the conservation of biological diversity. In Conservation biology: the theory and practice of nature conservation preservation and management. Chapman and Hall Ltd, New York.

[31] Gentry, A. H., and Vasquez, R. (1988):. Where have all the Ceibas gone? A case history of mismanagement of tropical forest resource. Forest Ecology and Management, 23: 73-76.

[32] Western, D. and Pearl, M. (1989): Conservation for the Twenty-first Century (eds). Oxford University Press, New York. 